\title{
EXAMINATION OF SELECTED MICROPARTICLES FROM THE SENTIK GLACIER CORE, LADAKH HIMALAYA, INDIA
}

\author{
By Emily Goss, Paul A. MAyewski, and William Berry Lyons
}

(Glacier Research Group and Department of Earth Sciences, University of New Hampshire, Durham, New Hampshire 03824, U.S.A.)

\begin{abstract}
Several characteristics and interpretative comments are reported for microparticles from selected samples in the Sentik Glacier core. Four basic morphologic groups are defined: platy, angular, biogenic, and anomalous.
\end{abstract}

RÉSUMÉ. Étude de certaines microparticles de la carotte du glacier Sentik, massif du Ladakh. Himalaya, Inde. On présente plusieurs caractéristiques des microparticules provenant d'échantillons de la carotte du glacier Sentik ainsi

As an addendum to glaciochemical interpretations resulting from our studies in the Indian Himalaya (Lyons and Mayewski, 1983; Mayewski and others, 1983, 1984), we present an account of Scanning Electron Microscope (SEM) and Energy Dispersive Atomic X-ray EDAX) analyses conducted on seven randomly distributed samples from our $16.6 \mathrm{~m}$ core from Nun Kun, Ladakh Himalaya (Mayewski and others, 1984).

Approximately $16 \mathrm{ml}$ was removed from each sample and filtered through a $20 \mathrm{~cm}^{2}$ Millipore T.M. filter system using $0.5 \mu \mathrm{m}$ Millipore membrane filters. Each filter was then put in a covered petri dish and stored at $60^{\circ} \mathrm{C}$ for several days. Approximately $2 \mathrm{~cm}^{2}$ from each filter was mounted on aluminum viewing studs and coated with 0.2 $\mathrm{nm}$ of a gold and palladium combination. A total of 46 pictures and 37 EDAX scans were finally produced from the samples, from which four basic morphological groups are differentiated (platy, angular, biogenic, and anomalous). A description and interpretation by morphology follows:

1. Platy (Fig. 1a) - characterized by length (range 13-160 $\mu \mathrm{m})$ and width (range 13-83 $\mu \mathrm{m}$ ) much greater than thickness, and "flaky" cleavage. A majority of the particles in this group had EDAX scans dominated by $\mathrm{Si}$, $\mathrm{Al}$, and $\mathrm{K}$, and for some particles associated $\mathrm{Fe}$ and $\mathrm{Mg}$ in place of $\mathrm{K}$. They probably consist of sheet silicates

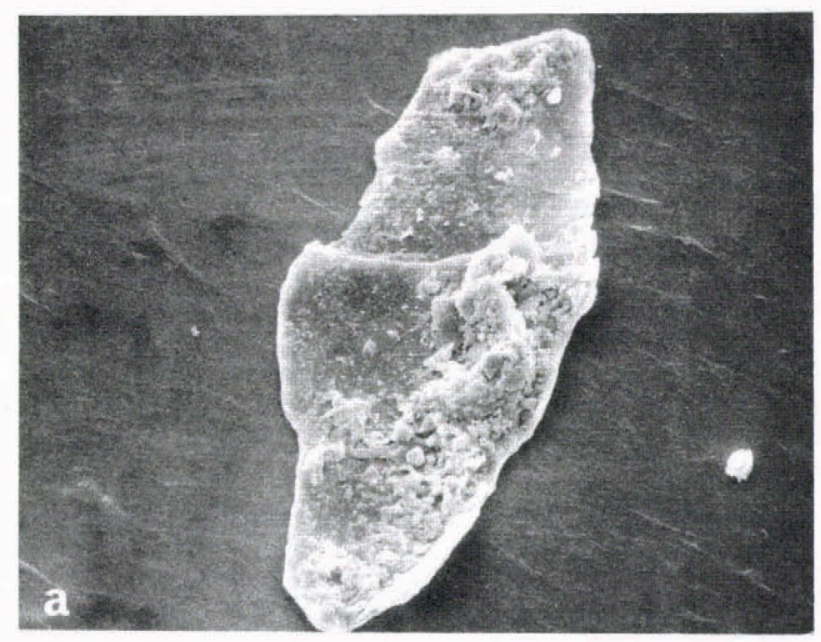

que leur interprétation. Quatre groupes morphologiques sont distingués: applaties, anguleuses, biogéniques et anormales.

Zusammenfassung. Prüfung ausgewählter Mikro-Partikel vom Bohrkern des Sentik-Gletschers, Ladakh-Himalaya, Indien. Einige charakteristische und interpretatorische Bemerkungen für Mikro-Partikel aus ausgewählten Proben des Bohrkerns vom Sentik-Gletscher werden mitgeteilt. Es lassen sich vier Gruppen von Grundformen feststellen: platte, eckige, "biogene" und unregelmässige.

(clays) derived from crustal weathering. The size range of the particles would suggest a local source (Mayewski and ohters, 1984).

2. Angular (Fig. 1b) - characterized by length (range 9-296 $\mu \mathrm{m}$ ), width (range 11-130 $\mu \mathrm{m}$ ), and an apparently equal range in thickness with $90^{\circ}$ or $60-120^{\circ}$ cleavages. A majority of the particles had EDAX scans of $\mathrm{Si}, \mathrm{Al}$, and $\mathrm{K}$ with in some cases $\mathrm{K}$ replaced by $\mathrm{Ca}$ and $\mathrm{Mg}$. These particles are probably feldspars derived from a relatively local crustal weathering source (Mayewski and others, 1984).

3. Biogenic - characterized by a wide range in size from 7 $\mu \mathrm{m}$ to $140 \mu \mathrm{m}$ in diameter. EDAX scans suggest a composition with few if any elements having atomic numbers greater than 10. By qualitative inspection, these particles comprise approximately $5 \%$ of the total number of particles observed in this study. Examples include diatoms (Fig. 1c) and pollen (Fig. 1d). These particles have potential for future study as both source indicators and as seasonal stratigraphic markers.

4. Anomalous - characterized by a wide variety of size ranges and EDAX scans. This group is a composite of all particles that do not fit in other groups. They comprise

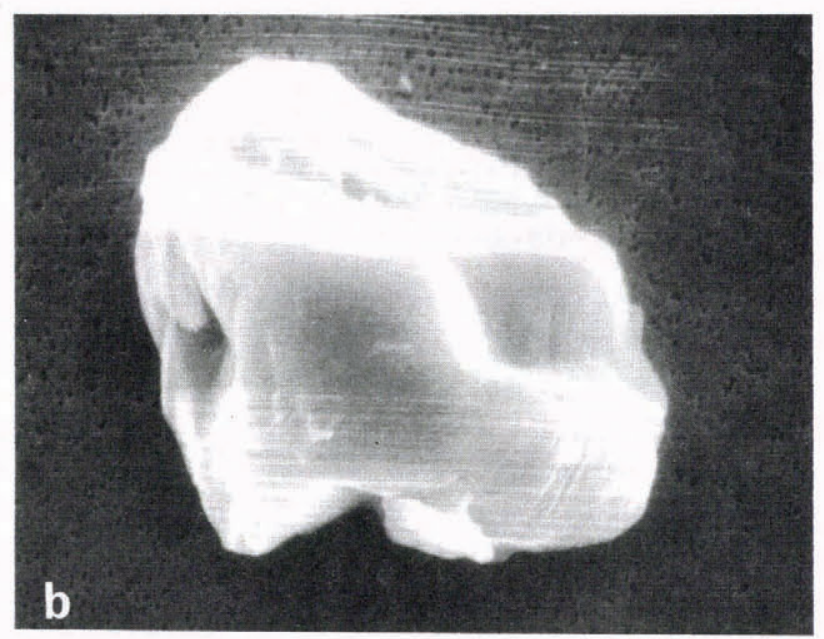



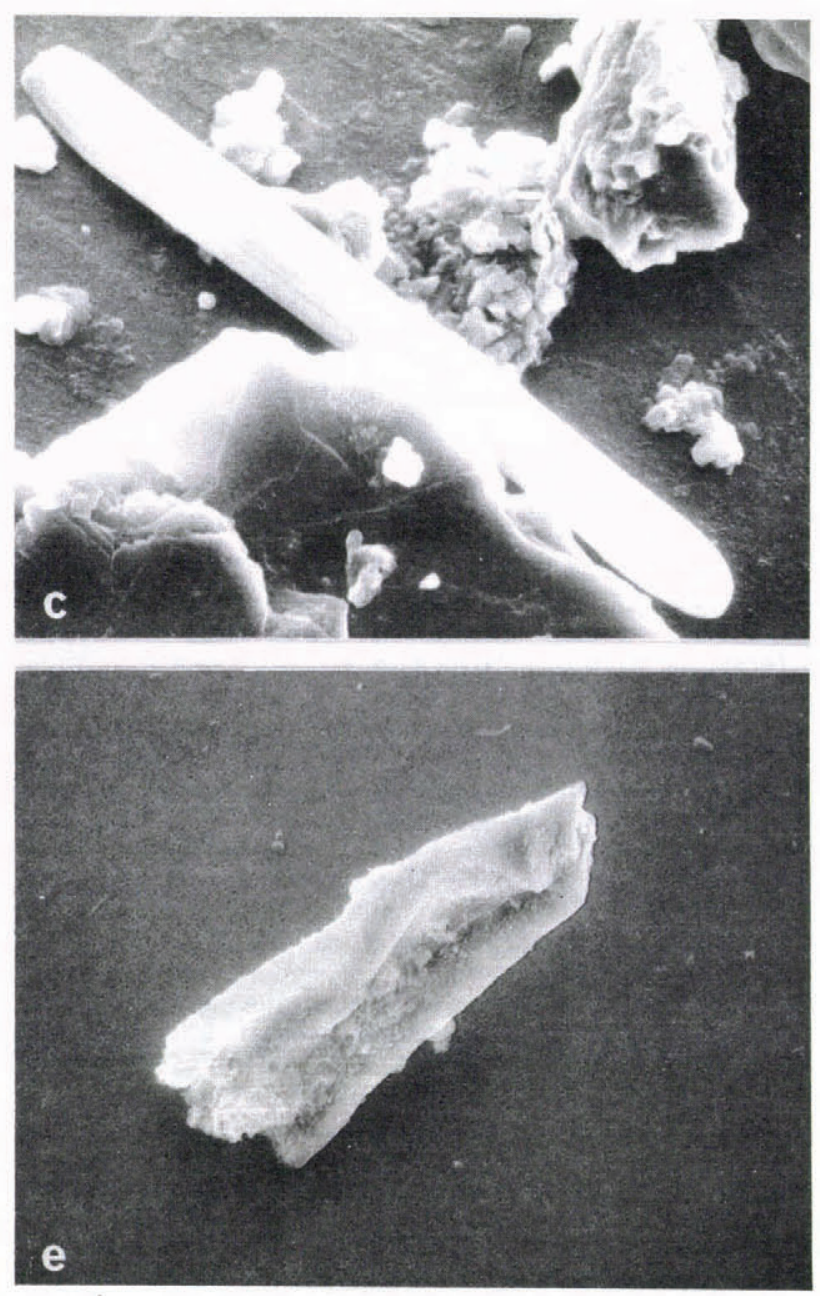

Fig. 1.a.Example of platy group; $160 \mu \mathrm{m} x 83 \mu \mathrm{m}, x 337$

b. Example of angular group; $9 \mathrm{\mu m} \times 11 \mathrm{\mu m}, x 4235$.

c. Example of diatom; $8 \mu \mathrm{m} \times 90 \mu \mathrm{m}, x 948$.

d. Example of pollen grain; $43 \mu \mathrm{m} \times 52 \mu \mathrm{m}, x 827$

e. Example of anomalous group; Ca-rich, $7 \mu \mathrm{m} x 11 \mathrm{\mu m}, x 4554$.

f. Example of anomalous group; Ti-rich, $38 \mu \mathrm{m} x 11 \mathrm{\mu m}, x 1301$. approximately $15 \%$ of all particles viewed. Examples include a particle with a distinctly high $\mathrm{Ca}$ concentration (Fig. 1e) and one with a high $\mathrm{Ti}$ concentration (Fig. 1f). These particles have the potential for being useful in uniquely defining source areas.

\section{ACKNOWLEDGEMENTS}

This research was supported by U.S. National Science Foundation grant INT-80-03175. We greatly appreciate the assistance rendered by M.M. Ecker of the UNH Electron Microscope Facility.

\section{REFERENCES}

Lyons, W.B., and Mayewski, P.A. 1983. Nitrate plus nitrite concentrations in a Himalayan ice core. Geophysical Research Letters, Vol. 10, No. 12, p. 1160-63.

Mayewski, P.A., and others. 1983. Chemical composition of a high altitude fresh snowfall in the Ladakh Himalayas, by P.A. Mayewski, W.B. Lyons, and N. Ahmad. Geophysical Research Letters, Vol. 10, No. 1, p. 105-08.

Mayewski, P.A., and others. 1984. Interpretation of the chemical and physical time-series retrieved from Sentik Glacier, Ladakh Himalaya, India, by P.A. Mayewski, W.B. Lyons, N. Ahmad, G. Smith, and M. Pourchet. Journal of Glaciology, Vol. 30, No. 104, p. 66-76. 